\title{
Doing Good Can Be Good Business
}

\author{
Whitney Peake (Western Kentucky University)
}

KEYWORDS: Sales, Marketing, Advertising, Social Media \& Networks, Family Business, crisis management.

Family businesses are often seen as foundational businesses in their respective communities, providing time, energy, and financial resources and gifts. Doing good is no doubt good marketing, but consumers are unable to reward businesses for such behaviors if they are unaware of the good deeds. Whether or not family businesses engage in "doing good" with the knowledge that their community may reciprocate by patronizing the business, they should get credit for the work they conduct in the community so consumers can factor this into purchasing decisions. As some places begin to reopen, now is an ideal time for family businesses to showcase the good they have done in their communities. Below are five quick tips for how to do good, share it with the community, and work to maintain goodwill with customers during these unprecedented times.

\section{Document do-gooding}

The local family-owned franchise, Donato's of Bowling Green, KY, gave away 1600 pizzas in two very well setup, social-distancing conscious drives to families with food insecurity in the county. The owner, Spence Sheldon, posted and shared information about the food drives on social media and had high engagement with posts. Given the substantial food insecurity within the county, this good deed did not go unnoticed by locals. Another example is the generosity of a local plastic surgeon, Dr. Salameh, who chronicled the delivery of gifts of skin cream to doctors and nurses at local hospitals to help repair their skin after wearing masks all day. This showed appreciation to the medical staff on the front line, highlighted the good deed, and gained a substantial amount of social media "buzz" for the plastic surgeon's business. Now, the recipients are showcasing before/after photos, which continues to generate likes and views. While these businesses were acting out of altruism, these acts matter to many consumers in making purchasing decisions.

\section{Show how you'll continue to care for customers}

Consumers have short attention spans, so filming short videos about how the business cares about safety and showcasing what is being done through video posts on YouTube, Facebook live, or Instagram can garner customers' trust and encourage customers to reengage physically with the business when it reopens. Most smart phones have the capability to shoot a video that is sufficient quality for social media, and if you do not have the skills or interest in filming these videos, your employees may.

Social media videos and posts reassure clients or customers what is going on "behind the scenes." Dr. Salameh, mentioned above, regularly posts videos and photos of procedures and new equipment. During the crisis, he launched a YouTube Channel to supplement his other social media formats. However, he has also used social media during the closures to notify potential patients of Zoom consultations and how the staff would care for patients as private, elective medical facilities began to reopen. This provided patients reassurance of how the office would function and look upon reopening.

Perhaps you have seen the National Cowboy Museum's posts by Tim Tiller, the head of security. He took over social media for the museum during the shutdown and grew Twitter followers to over 300,000 and Instagram and Facebook accounts to nearly 100,000. He was the only employee on site during the shutdown. Tim Tiller took care of maintaining security but also promoted the museum to an entirely different level, something that was certainly not part of his original job description.

\section{Partner with other family businesses}

Family businesses are often stronger when they band together. Why not showcase the excellent work other
Copyright $@ 2020$ The Authors. Entrepreneur \& Innovation Exchange is published at EIX.org. This is an open access article under the terms of the Creative Commons Attribution-NoDerivs License, which permits use and distribution in any medium, provided the original work is properly cited and no modifications or adaptations are made. View EIX.org Authorship Terms at https://eix.org/terms
FamilyBusiness 
businesses are doing in the community? Share other family businesses' posts, join their initiatives, and photograph, video, and share the good local family businesses are doing together. For example, A Cut Above Lawn Care in Bowling Green, KY, shared posts multiple times a day highlighting other local businesses, like Nat's Outdoor Sports, Vision Source, Drobocky Orthodontics, and local restaurants. Every businesses' social media pages have different market segments that follow them. This may help a business cross the paths of new customers in the service area, and if/when these businesses need commercial lawncare service, A Cut Above Lawn Care is likely at the top of their list.

\section{Engage the WHOLE family in doing good}

Although this is a strange time, it is an opportune one to involve the family in promoting the business. A good friend of mine who is a new product manager in a firm told me that he is engaging his 10-year-old daughter in marketing and record-keeping. He has been surprised by how helpful she has been in designing aesthetically pleasing presentations and crafting reminders on where the product stands in the regulatory application process state-by-state. This friend gets to delegate some less difficult tasks and she is excited to include these activities in her homeschooling. Family businesses can use this time to video how they are involving younger generations, caring for the community alongside their families, providing products to first responders, etc. Bringing older kids on with social media savvy to help promote the business, for example through TikTok, Instagram, and other social media sites can help take a load off parents and perhaps give children increased buy-in to business activities.

\section{Find non-monetary ways to give}

As the cash crunch continues, no doubt both businesses and consumers are hard-hit. Consumers are more DIY conscious as they spend more time at home during the pandemic. Care comes in all different shapes and sizes. Perhaps care for the community is sharing just enough of the "secret sauce" recipe to allow them to do some of the work at home. Is there a way to showcase how to prepare a favorite baked good, home improvement project, vehicle preventive maintenance, financial planning task related to the business that customers can begin at home? This can help customers through a trying time and build future loyalty for your family business. For example, a local family-run business, Tabulated Organizer, has been providing weekly DIY home organization plans called "Tabulated Tips," for Instagram followers, as well as Facebook live posts on organization that have been very popular and well-received. These types of activities show your customers that you care for them, keep them engaged during these times of social distancing, and hopefully lead to loyal customers once the economy returns.

In the age of social media, it is critical to work to promote all the good family businesses are doing, especially in such a difficult time for both business owners and their customers. In order for customers to respond to these businesses for their altruistic behaviors, they must know about them. So, while it may feel inauthentic to chronicle the "good" a family business is doing in the community, it is essential so that customers can factor that into their purchasing decisions. 